\title{
Race in International Relations
}

Srdjan Vucetic (University of Ottawa) \& Randolph B. Persaud (American University)

To appear as Ch. 3 in Persaud \& Alina Sajed (Eds.), Race, Gender, and Culture in International Relations: Postcolonial Perspectives. London: Routledge, 2018.

[10,000 words]

- Introduction

- Race as theory

- Race in global society

- Race and global development

- $\quad$ Race and security

- Conclusion

\section{Introduction $^{1}$}

Race as a concept has always been difficult to define. Racism as a practice, however, has been more easily identified, both in historical and in contemporary time frames. How could this anomaly exist? Part of the answer may be found in a methodological preference through which scholars seek to define what race 'is', and then proceed to apply it in the real world of experience. A similar observation holds with respect to the role of race in international relations. This chapter will allow us to more clearly specify the concept of race and its relationship to international relations by examining how race has functioned, and with what practical effects. 
Our historical-genealogical approach has three advantages. First, it begins with a recognition that it is in actual history, (not theory or abstract principles) that racism has asserted itself and where race emerged as a general organizing category (Painter 2010). This occurred on a global scale, which means that race operates everywhere, not just in some countries. Next, as the anthropologist Michel-Rolph Trouillot (1995) has noted, there is a difference between what happened and what is said to have happened; indeed, the latter always distorts the former, sometimes massively so. The writing of history in the Western Academy has played a major role in shaping how we see the world today, and how that world has come to be, especially as it moved from 'primitivity' to modernity. This directly relates to the third advantage of our historical-genealogical approach — the fact that it is fundamentally in sync with the postcolonial perspectives on international relations specifically (see the volumes edited by Chowdhry \& Nair 2003; Seth 2013; Quỳnh \& Shilliam 2016), and on world historical development more generally (Young 1995). In our usage, the postcolonial approach is a kind of history from below, or what a group of scholars in India (Guha 1982; Spivak 1988; Chakrabarthy 2000) called subaltern history-history whose task is to challenge, modify, and correct the Eurocentric history which is popular in international relations, and on which basis most of international relations theory is built. The subaltern turn obviously built on the critique of Orientalism (Said 1979).

Our argument follows from this perspective: in international relations, race has two broad avenues of occurrence. One is what we shall call actually existing racism, meaning racism that has been practiced as action. The other avenue is international relations scholarship in which race manifests itself through both commission (what is written and taught), and omission (what is left out, minimized and, indeed, silenced) (Chowdhry and Rai 2009; Mittelman 2009). To make this argument, we first discuss the concept of race, and then devote one section each on global 
society, economic development, and security. In the concluding section, we reflect on the future of race and racism in world politics.

\section{Race as Theory}

The scholarship we read in international relations has been written only over the past century, and most of this writing has not only taken place in Europe and the United States (with important contributions from Australia and Canada), but also from a Western perspective, by Western scholars, and by and large with the subtle or explicit intention of advocating, defending, and or legitimizing Western interests, values, and beyond. Why does this matter, and what does any of this have to do with race? Those are perfectly legitimate questions.

Let us start with a premise that race is itself a product of culture, and practices of race and racism recursively feed back into culture. They are, in other words, reciprocally constituted. Culturally, the Western construction of the Third World is more likely to taken as authoritative knowledge, but not the other way around. Fig. 1 below presents a simplified picture of the ways the West sees the Third World-a.k.a., the 'rest', 'The East', 'the Global South', and itself, across ten sectors of life, ranging from 'civilization' to 'religion'.

\begin{tabular}{|l|l|l|}
\hline \multicolumn{2}{|l|}{ Fig. 1. How the West sees the Rest versus the West } & The West \\
\hline & The Third World & Free; Developed \\
\hline General description & Developing/Backward & Modern \\
\hline Civilization & Ancient to Non-Existent; anachronistic; & Mocted as Western. \\
& & \\
\hline
\end{tabular}




\begin{tabular}{|c|c|c|}
\hline Knowledge & Local; parochial; religious & Universal; philosophical \\
\hline Technology & Consumers; followers & Producers; innovators \\
\hline Culture & Folk; superstition; exotic, parochial & $\begin{array}{l}\text { Cosmopolitan; rational; } \\
\text { scientific, problem-solving }\end{array}$ \\
\hline Nation state & Fragile; corrupt & Strong; functional \\
\hline $\begin{array}{l}\text { Economy and work } \\
\text { attitudes }\end{array}$ & $\begin{array}{l}\text { Backward; stagnant; emerging } \\
\text { Mañana, mañana }\end{array}$ & $\begin{array}{l}\text { Advanced, postindustrial, } \\
\text { Industrious }\end{array}$ \\
\hline Temporal Mindset & Backward looking & Forward looking \\
\hline $\begin{array}{l}\text { Security, War and } \\
\text { Peace }\end{array}$ & $\begin{array}{l}\text { Rule-breaking; terror-oriented; Nuclear } \\
\text { states lack rational faculties for } \\
\text { successful deterrence. }\end{array}$ & $\begin{array}{l}\text { Humanitarian; defenders of } \\
\text { the civilized world; global } \\
\text { leadership; global heroes }\end{array}$ \\
\hline Concept of History & Trapped in colonial era and slavery & $\begin{array}{l}\text { Progressive; rational } \\
\text { unfolding of Enlightenment } \\
\text { values }\end{array}$ \\
\hline Religion & $\begin{array}{l}\text { Superstition; violent; 'too many of } \\
\text { them' }\end{array}$ & $\begin{array}{l}\text { Christianity, especially } \\
\text { Protestantism }\end{array}$ \\
\hline
\end{tabular}

Source - Authors

The basic take away here is the self-conception of the West as scientific, rational, forward looking and industrious. These attributes are taken to be innate at times, while in other situations they are taken to be a part of European culture, that is to say, a product of European ingenuity. 
The Third World collapsed into an undifferentiated mass, is formulated into a backward and superstitious people who are bogged down by the memories of colonialism and slavery. The Third World lacks basic political equipment, that is, the modern state, needed to bring forth economic and social development (Landes 1990; Harrison 1998).

As mentioned in the introduction, such constructions are usually called Orientalist $-\mathrm{a}$ term originating in the cultural studies of the 1970s for the West's, a.k.a., the Occident's, patronizing representations of the 'East' and specifically the Arab world. Orientalist elements can be found everywhere in the Western thought, not just in international relations (Walker 2006, Doty 1996, Hobson 2012; van der Pijl 2014). The European philosopher GWF Hegel had some respect for Asian culture but was firm in the belief that others, and especially Africans have not contributed much to history (Buck-Morss 2009). In more contemporary time, writers such as Samuel Huntington and Lawrence Harrison (2001) believe that some places such as Latin America are static due to the adherence to Catholic values - a claim that also harks back a separate style of thought in the Protestant world that Spanish speakers sometimes call the 'black legend' or $l a$ leyenda negra (De Guzmán 2005). Thus, Harrison argues that while Catholicism is keeping Latin America back, Asians are developing because they have Protestant values. The key values are apparently thrift, postponement of pleasure, hard work, and a high propensity to save.

Postcolonial scholars critique the Orientalist construction of the Third World, with some more directly arguing that Orientalism is an explicit form racism. Inayatullah and Blaney in their acclaimed book International Relations and the Problem of Difference link Orientalists theories of socio-economic development to modernization theory which advocates the globalization of Western development strategies, and especially its neoliberal form. To better understand 'development', we should therefore begin by situating modernization theory in the modern 
colonial encounter itself, paying due attention to 'both global structures and the meanings and intentions of actors' (Inayatullah and Blaney 2004, 125; also see McCarthy 2007; Bhambra 2007; Sajed 2009).

The postcolonial scholarship, which goes back at least to W.E.B. Du Bois, has offered no shortage of penetrating accounts of the relations between race and racism on the one hand, and labor exploitation, patriarchy, sexuality, militarism, colonialism, and migration on the other. But this scholarship was always resisted. Du Bois, who by any reasonable measure counts as one of the twentieth century's intellectual powerhouses, was effectively silenced throughout his professional life and long afterwards simply because he was African American. Other African American scholars who followed in Du Bois's footsteps-Vitalis (2016) describes some of them in a highly praised book on the origins of American international relations-had similar professional and personal experiences.

None of this should be surprising. As Vitalis highlights, what we know today as international relations was, at its founding, understood to be a discipline dedicated to 'race development'. The journal that we know today as Foreign Affairs, was the original journal for American international relations scholarship, and its title was Journal of Race Development. The stated purpose of the journal was to present ideas about what the methods that 'developed peoples,' and specifically colonial administrators, could use to help 'uplift' backward' and 'under-developed' races. Indeed, contrary to what almost all standard textbooks say, the object of inquiry that gave rise to the discipline of international relations was not 'the international' so much as 'the interracial.' The goal of that inquiry, in turn, was the protection of white supremacy (Mills 2015).

In addition to struggling with their disciplinary history, today's international relations scholars are also struggling with the concept of race itself ${ }^{2}$ (Malik 2009). This, too, should not be 
surprising. Two scholars can agree that races do not exist in a natural (biological) sense as well as that our world is characterized by actually existing racism, yet they can still disagree about the best way to conceptualize race. Philosophers of race have spent a lot of time thinking about this issue (Vucetic 2015). At one level, conceptualization debates are always about ontology, the branch of philosophy that deals with the issue of the nature of reality. If one is to judge by institutions that help administer justice or wealth, affirmative action policies, national census questionnaires, media caricariturizations of 'identity politics', forensic DNA assessments or personalised genetic genealogies, then race exists-it is 'out there to know.' If one is to talk to natural scientists, however, then race is illusory. We know that phenotypes and genotypes - for example, body hair genes - are not indicative of biological or genetic fixity, they would say. Both perspectives are in fact correct. Race exists as a social phenomenon, which means that it exists as a relation, not a 'thing'. 'Brown people', 'Caucasians', or 'old stock Canadians' do not exist independently of the acts of categorization, all of which are historically context-dependent.

Thousands of scholars in fields such as anthropology, cultural studies, history, and sociology today devote their entire careers studying racialization-social relations and processes that (re)produce race by articulating and legitimizing intragroup unity and intergroup incommensurability. ${ }^{3}$ Why were the Irish during the Victorian era racialized as white in India, but as "less than white" in the British Isles or North America? Are the residents of Moscow who hail from the Caucasus and Central Asia more likely to be racialized as black (chorni) today than they were in the Soviet period? Could it be that hukou, a system of controlling residency and movement of workers in contemporary China, is actually racializing the country's urban-rural divide? The purpose of researching these questions is not understanding what race is (or is taken to be) so much as what race does - that is, about the consequences of racialization on the 
differentiated distributions of power, authority, recognition, wealth, worth, resources, entitlement and opportunity. As Lentin (2015) has argued, understanding this 'performativity of race' is necessary for the success of anti-racist activities today; to challenge the racisms that underpin today's societies, we must first develop an intimate knowledge of how race mutates to fit the contemporary context and time (also see Kendi 2016).

Social theoretic and social scientific research on contemporary manifestations of racism occasionally appears in books and articles with seemingly paradoxical titles such as 'new racism', 'racism without racists', 'racism without races', and even 'racism without racism'. These effectively emphasize both the longevity and the malleability of racialized realities. Some of this research is also experimental. The scholarship on habits-this connects turn-of-thetwentieth century social theory to twenty first century social neuroscience-shows that humans create and maintain their worlds informally, implicitly and unselfconsciously and that racialized worlds are no exception. Relatedly, many cognitive psychologists have long demonstrated that racial prejudice can be present even among those who consistently reject the existence of races and otherwise hold reliable anti-racist attitudes—-the so-called implicit bias.

Most reputable news media outlets today do not shy from reporting on how racialized systemic structural advantages and disadvantages impact people's lives on a global scale. Read about the experience of Aboriginal and Torres Strait Islander communities in Australia, Bolivian migrant workers Argentina, Dalit people in Andhra Pradesh, Hispanics in Arizona or temporarily protected asylum seekers in Austria and you are likely to observe that most majoritarian anxieties over the alleged cultural incompatibilities involving minorities revolve around race and racism. The same goes for the stories about the so-called culture wars-what is and is not remembered about the past, and why. For some of you, the most thought-provoking pieces will be those that 
prompt you to think about your own complicity in racialized relations of power-a piercing editorial on why 'we' should be held accountable for 'their' conflict or poverty, or perhaps an astute op-ed or two on the concepts of 'white privilege', 'habits of whiteness,' 'white ignorance', 'white innocence' or 'white fragility.'

When consuming the media reporting on race and racism, it is important to keep a critical mind about the 'latest scientific research on race.' As we show in the next section, the history of the political misuse and abuse of such research is long and sordid. Sample recent newspaper articles about race from the perspective genomics revolution and corollary sequencing of the genomes of human brings (the interpreting of the DNA that make up a person's genome) and you are likely to discover no shortage of misleading and unsubstantiated claims. In some cases, said articles will be authored by professional provocateurs who will try to pick your intellectual pockets with claims that new scientific findings show that human races are real in the genetic sense or that genetic differences among races may explain changes in social behaviors and institutions during recent evolution. It is also a good idea to read what scientists are actually saying. Recent claims by evolutionary psychologists that race may be a by-product of evolved cognition of the human brain-meaning the result of evolution by natural selection, whereby tribal identity formation came to depend on some sort of perceptual saliency of skin color-are speculative at best.

This brings us to another major conceptual question that has kept philosophers of race awake: how should we talk about race in the first place? The relevance of this question is self-evident once we accept that language has the power to reify, or naturalize, what is socially constructed. Most people tend to be 'conservationists', a term for a position that racial categories should be conserved for the purposes of policy and politics. In contrast, 'eliminativists' contend that should 
be eliminated from public discourse. This camp includes political liberals who think they live in color-blind and/or post-racial societies, conservative polemicists who think minorities should "get over it" as well as a relatively small group social scientists and social theorists who think that the meanings of race could be more effectively subsumed under a 'nearby' category such as class or ethnicity.

The problem with the eliminativist position from the perspective of this volume is that it erases the philosophical and theoretical basis for anti-racist politics that motives the very idea of postcolonial scholarship in the first place (see Box No. 1 and also other chapters in the book). This was a point Du Bois made a century ago: critical confrontation with race is the necessary step in the possibilities of overcoming the problem of race.

\section{Box No. 1: Intersectionality}

Although conservationists reject attempts to substitute race for class or ethnicity, they tend to readily accept that race, class, and gender-to mention but three relations of power-should be analyzed together. Labelled intersectionality, this theory comes from the long tradition of Black feminist thought in the U.S. Kimberlé Crenshaw, who coined the word in the 1970s, has argued that this tradition spans nineteenth century thinkers and activities like Anna Julia Cooper and Maria W. Stewart to the more recent figures like Angela Davis, Audre Lorde and Deborah King.

Intersectionality helps advance anti-racist politics without reifying race while also providing a powerful new lens for examining the multiplicity of ideas, discourses, institutions, policies and practices that contribute to the exclusion and oppression of some people and not others in specific contexts (see 'Further readings' below). 


\section{Race in Global Society}

Most histories of race begin with European overseas expansion in the early modern period. What made this expansion possible was mass-scale imperial dehumanization-an effort to affix the indigenous peoples in the Americas and Africa as non-human or less-than-human indistinguishable from livestock for the purposes of their enslavement, dispossession, exploitation and extermination. Behind this effort was a simple cost-benefit analysis: treating some humans as indistinguishable from livestock made social domination easier than accepting their rights and recourse to justice. ${ }^{4}$

Historians of race typically differentiate among multiple but inter-related processes of racial dehumanization that occurred in modernity, thus again emphasizing that race is a relation and not a fixed identity. Depending on the time and place, race could therefore mean 'civilization,' 'spirit', 'blood', 'nature', or 'culture', — and sometimes all of the above at once. This is why the word racism sometimes comes with adjectives 'theological', 'cultural', 'biological' and 'scientific' (Frederickson 2002).

The mid-sixteenth century Spanish theological debate on whether the 'Indians' — the newly 'discovered' population of the Americans-were 'natural slaves' or not paralleled much earlier distinctions between savages and barbarians (Todorov 1999). Savages referred to people who supposedly lacked basic forms of law and order, sometimes even reason. Barbarians in contrast 'merely' lacked culture and civilization. (The ancient Greek word bárbaros — a similar word also exists in Sanskrit and Latin-described people whose foreign language sounded as the onomatopoeic 'bar bar bar'). Along the same lines, early Christian theological discourses on the inferiority of Jews and Muslims later came to inform secular forms of cultural racism, including some present-day versions of anti-Semitism and Islamophobia. ${ }^{5}$ 
The transatlantic slave trade-the human trafficking of Africans across the Atlantic-was an especially important site of modern imperial dehumanization. What matters here is the construction of the human body as the primary site and marker of difference-skin color, hair type, and facial features. Enslaved Africans became the inferior 'black' and European slavers the superior 'whites'. Not all scholars of race will agree that color hierarchies are a modern invention, but they will all agree that slave trade was integral for the development of the socalled biological racism. ${ }^{6}$ Contemporary media preferences for the white European bodyHollywood-, and in fact Bollywood-style whitewashing, for example-are one of the many legacies of this history.

By the late eighteenth century, cultural and biological racisms were being enmeshed in what we today call scientific racism - a pseudo-scientific body of thought that in essence sought to prove the inherent superiority of the cultures and races of the West, meaning of Europe and its overseas offshoots (Watson 2001; Painter 2010). A good example of scientific racism is the first volume of Journal of Race Development, published in 1910. In it, one can observe how ideas about civilization and color combined with the latest advances in the natural and human sciencesevolution and eugenics, for instance-to inform the politics and policy of colonial management. Many striking example of scientific racisms can be found in the Nazi ideology, starting with Adolf Hitler's division of humanity into Aryan "founders of civilization" (the "racially clean and unmixed" North Americans belonged to this group), "bearers of civilizations such as the Japanese, and "civilization-destroyers," principally the Jews.

In this period, scientific racism naturally became enveloped in a so-called standard of civilization, a conceptual-legal yardstick, that individual and institution actors in the West, had previously used to adjudicate the relative simplicity or complexity of non-Western peoples with 
whom they interacted. This concept, originating in the early fifteenth century, is central to understanding the development of modern international society. From a Eurocentric point of view, it was European expansionism that unified a number of different regional systems into an oceans-spanning international society characterized by the ideas, institutions and practices first invented or perfected in Europe-those related to diplomacy and international law, for example. As a general rule, only polities defined by themselves and others as 'European' and later 'Western' recognized each other as equal sovereigns—an exclusive club of territorially sovereign states and empires of different sizes (Gong 1984, Grovogui 1996, Shogo 2009, Benton 2010). Put down the Eurocentric lens, however, and you will see a much richer picture of international social life, the outstanding case in point being relations involving indigenous polities (Crawford 1994, Stewart-Harawira 2005, Lightfoot 2016).

As the nineteenth century was the high point of European imperialism, the standard of civilization gained power on a global scale and created an international hierarchy that in many respects last to this day. To begin with, no colonial intervention could take place without a 'civilization debate'- that is, on whether the target area can be, or should be, civilized through colonization. The U.S. debate over what do in the Caribbean and the Philippines after the Spanish-American war is an example (Murphy 2009). Similar debates surrounded colonial partition projects, some of which were continental and sub-continental in scale: the post-1881 'scramble for Africa' or the 'carving up the Chinese melon' after 1895. Even the 1947 division of British India into India and Pakistan can be seen in this light given that it was completed in a month and half by a boundary commission headed by Sir Cyril Radcliffe, a London lawyer who until then had never been east of Paris. An excerpt from W.H. Auden's 1966 poem 'Partition': 
[‘...]We can give you four judges, two Moslem and two Hindu,

To consult with, but the final decision must rest with you.'

Shut up in a lonely mansion, with police night and day

Patrolling the gardens to keep the assassins away,

He got down to work, to the task of settling the fate

Of millions. The maps at his disposal were out of date

And the Census Returns almost certainly incorrect,

But there was no time to check them, no time to inspect

Contested areas. The weather was frightfully hot,

And a bout of dysentery kept him constantly on the trot,

But in seven weeks it was done, the frontiers decided,

A continent for better or worse divided [...]

As architects of modern international order, white Europeans considered only themselves to be competent to adjudicate the civilization of others. When the Haitian Revolution, 1791-1804, overturned the slave system in Saint-Domingue, the crown jewel of the French empire and in fact the entire colonial world, most European intellectuals at first refused to believe it. The notion that a successful slave revolt—on this island alone the colonizers had previously quashed at least eight such revolts—could give birth to an actually existing and radically revolutionary black polity in the New World island was simply unthinkable to them (Trouillot 1995: Ch. 3). Years passed before France moved to recognize Haiti, but only on the harshest of terms for the latter. In 
1825, Haiti's government agreed to repay an 'independence debt' to compensate French slaveowners for 'lost property', meaning slaves who had won their freedom-a transaction that was in fact illegal in then French and international laws. To finance this exorbitant sum-with standard adjustments, it hovers around US $\$ 30$ billion in today's money-Haiti's government also committed itself to working with banking institutions in Paris, with a predictable effect on the fairness of interest rates and fees. ${ }^{7}$

The fate of Haiti speaks volumes about white supremacy. An international society maintained by and for white Europeans could not tolerate an American nation birthed in a revolt of an enslaved people of African descent. This is why no other colonial power with interests in the Caribbean supported Haiti over France; in fact, the colonial powers scrambled together to prevent similar revolutions from occurring elsewhere. Their fear was palpable because Haiti's leaders-many of them enlightened men of letters-had the nerve to outlaw slavery (Article 12 of the 1805 constitution) as well as territorial aggrandizement and foreign interventions (Article 36). Contrast this with the nineteenth century experience of the United States. Had the new Haitian state been a secessionist white settler colony practicing slavery and expansionism, perhaps it too would have swiftly joined the society of states.

Another example of white supremacy at work is the attempt of the Japanese delegation at the 1919 Paris Peace Conference to insert a 'racial equality clause' into the Covenant of the League of Nations (Shimazu 1998). At this time, Japan had indeed demonstrated its 'civilized' statehood by behaving like a Western power in every way-its state and society modernized, while its empire expanded. Yet, none of this impressed the white men who dominated the conference proceedings. U.S. President Woodrow Wilson who is widely cited as the great idealist of 
international relations in fact presided over the meeting that nixed Japan's demand for equal status (Lauren 1996: 80-95; Klotz 2017: 371).

A related, and equally dramatic, example of the operation of the racialized standard of civilization at the same conference was the introduction of a so-called mandate system-an arrangement for transferring the former German and Ottoman colonies to new sovereign authorities, namely those of the victorious European powers and Japan, according to the aforementioned standard-of-civilization schema (Shilliam 2017: 290). The mandate system later influenced the UN trusteeship systems (Toussaint 1956: 2-3) and thus today's international statebuilding debates (Sabaratnam 2017: Ch: 2).

It was after the World War II, the Shoah (Holocaust), decolonization, and the rise of human rights that international society began to transform itself into a somewhat more inclusive club. ${ }^{8}$ The word 'somewhat' is apt, however. A familiar example of the staying power of racism in the world is the 45th president of the United States, Donald Trump. Following a deeply racist and xenophobic campaign, Trump proceeded to enact white supremacy through White House policy_the 'Muslim ban', a new 'voter fraud' commission, refusals to condemn Nazism and neo-Nazis, etc. In doing so, he fueled racial hatreds to the point of inspiring white supremacists to murder people on the American streets. 'UN sounds the alarm over US racial tensions' was a page one headline in The Guardian on August 24, 2017. Another striking example of actually existing racism in today's "advanced liberal democracies" can be found in the practice of mandatory and indefinite detention for asylum seekers, the outstanding case in point being the latest iteration of Australia's 'Pacific Solution' (Lentin 2017, Vucetic 2012: 211). In many ways, racialization is as central for understanding state sovereignty, migration and borders today as it was a century ago (Klotz 2017; also see Box 2). 


\section{Race and Global Economic Development}

There is actually much more critical material on the impact of race and racism on global economic development than there is in international security. A good deal of this is due to the fact that before IR was penetrated by postcolonialism, critical gender studies, critical human security, and the political economy of climate change, Marxist and neo-Marxist were an integral part of the political economy debates of international relations (Dirlik 2003). That said, most of these scholars saw race (and gender) in terms of class relations, and more broadly within the exploitative relations of global capitalism. Marxists who stressed production rather than trade as the crux of capitalism tended to see race as a form of 'false consciousness', meaning that race was not a form of domination that emanated from the contradictions supposedly embedded in capitalism as an economic and social system. For Marxists, the proper corresponding ideology against capitalist exploitation should have been proletarian resistance aimed at a macro-structural transition from capitalism to socialism.

Marxist political economy, despite solid contributions to the critique of imperialism, generally disregarded race as a conceptual and analytical category. Karl Marx himself assumed that global capitalism would benefit places like India because it would transform the local culture, much of it assumed to be tied down by what Marx thought were superstition. In this sense, many Marxists, going back to Marx, and then through the period of Third World decolonization held on to notions of Western modernity even when offering critiques of militarism and imperialism. John Hobson argues that Marx and Engels explicitly supported imperialism, and further that their view of the non-Western world amounted to 'paternalist Eurocentrism'. Later classical Marxists 
including Lenin, Luxemburg, Hilferding, and Bukharin though anti-imperialist, had worldviews Hobson calls ‘subliminal anti-paternalist Eurocentrism' (Hobson 2012).

Despite these shortcomings, as Blaney and Inayatullah note in Chapter 7 Marxist political economy did not ignore the 'rest' in its accounting of the emergence of the modern world system. Nowhere was this more systematically done than in dependency theory and worldsystems analysis. These historically oriented branches of Marxism which were both influential from the 1960s through the mid -1980 s, therefore, did make some connections between racist ideology and the relations of exploitation and domination. Andre Gunder Frank and Immanuel Wallerstein drew race into their work more systematically, but only on a systematic basis after 1989. Before that, it was 'Third World' scholars such as Walter Rodney and Eric Williams who were insistent that global capitalism cannot be understood without the extraordinary role that race and racism played. If fact, much of what we would come to know as postcolonial critical political economy were already spelled out in Rodney's How Europe Underdeveloped Africa. The quotations from that book in Box 2 paint a good picture of a sort of Marxian postcolonial understanding of the world economic system and more broadly, the general structure of global political and cultural power embedded in the state system. Rodney's thinking illustrates what is really an intersection of Marxian political economy from the 1970s, and the more clearly defined fusion of that tradition with postcolonial economic critiques.

\section{Box No. 2: From Rodney's How Europe Underdeveloped Africa.}

'The developed and underdeveloped parts of the present capitalist section of the world have been in continuous contact for four and a half centuries. The contention here is that over that period Africa helped to develop Western Europe in the same proportion as 
Western Europe helped to underdeveloped Africa' (p. 75).

'Pervasive and vicious racism was present in imperialism as a variant independent of the economic rationality that initially gave birth to racism. It was economics that determined that Europe should invest in Africa and control the continent's raw materials and labor. It was racism which confirmed the decision that the form of control should be direct colonial rule' (p. 141).

'It can further be argued that by the nineteenth century white racism had become so institutionalized in the capitalist world (and especially in the U.S.A.) that it sometimes ranked above the maximization of profit as a motive for oppressing black people' (p. 89).

Immediately following WWII three major historical developments started almost simultaneously, namely, decolonization, the Cold War, and the dramatic rise of the United States as the unofficial leader of the Western world. All three of these global phenomena had major impacts on economic development, and all three were also implicated in actually existing racism that followed WWII. Decolonization ruptured the vertically-organized system of global economic relations between the European and Third World economies, though mostly in formal terms. The Cold War imposed a bifurcated, bipolar states system, at least in terms of international security, and especially so it terms of state-to-state security. These three developments formed a historical structure (Cox, 1987) which would eventually collapse in 1989. The disappearance of the Soviet Union in turn broadly coincided with the spectacular rise of globalization, which according to Dirlik is the form of a new world order. 
Decolonization did not end actually existing racism in the global political economy as new forms of racialities emerged, for instance, the legal, political, economic, and cultural imposition of apartheid in South Africa and Rhodesia (now Zimbabwe) as well as in Canada in a milder form, with its reserve system. We see the continued racialization of economic development both in theory and practice (Matlon 2016). In theory, the most influential contributors were hypermodernists, where the latter basically means following Western models, not only of economic development, but also of state society relations, and more broadly culture (Williams, Meth, \& Willis 2014). The metamorphoses of the actually existing racism led the Peruvian sociologist Anibal Quijano (2000) to propose the concept of the coloniality of power, meaning the continuation of relations of domination conjured up in the ideas, institutions, and material practices of global capitalism combined with new form of cultural Eurocentrism.

The racialization of the political economy of development had too principal dimensions, and they still do today. The sustained anti-immigrant politics in the West which is dependent on the Third World for both 'cheap' and high-tech labor is not only a fetter on economic growth, but also a matter of massive insecurity for immigrants and migrant workers (see Box No.3).

\section{Box No. 3 Race and Immigration}

It was a typically cold night in Olathe, Kansas on the evening of February 24, 2017. Two engineers, Srinivas Kuchibhotla and Alok Madasani, who worked at Garmin, the company that makes GPS devices, decided to do the usual - take a few drinks after work on a Friday night at Austins Bar and Grill. At 7.30 P.M. a white gunman walked into to the bar and opened fire on the two Indian immigrants. Srinivas, 32, died of his wounds. Alok, also 32, survived, but was seriously wounded. The gunman, 51-year-old Adam Purinton fled the scene and made his way 
to an Applebee's some eighty miles away in Clinton, Missouri. He told the staff at the restaurant he wanted to hide because he had shot two Iranians. A third person, Ian Grillot, a white young man of barely 24 , was also shot when he attempted to come to the assistance of the two Indians. Like so many immigrants, Srinivas must have come to the United States to enjoy what is called the American Dream. He was on his way as a qualified engineer working at a high-tech company in the American heartland. His family was with him, and he had friends, friends like Alok. Purinton also had a dream, but his was different. His dream it appears, is to rid America, save America, from those foreigners, those Muslims who are today, and have been for the longest time, portrayed as a fundamental threat to an otherwise ideal society. Before the gunshots the only previous contact between the Indian immigrants and their assailant were the words of Purinton - "get out of my country".

Sources:

http://www.thehindu.com/news/international/Indian-engineer-shot-dead-in$\underline{\text { Kansas/article17359339.ece }}$

https://www.nytimes.com/2017/02/24/world/asia/kansas-attack-possible-hate-crime-srinivaskuchibhotla.html

The first concerns the right of the Third World states and peoples to govern themselves. Discourses from the late nineteenth century were replete with the widespread belief in the Western world that colored people were not ready for self-government, and certainly not for leadership. The belief was itself ensconced in notions of Western white supremacy, and led to aggressive imperialism with the American military intervention in the Philippines, and the already well-known scramble for Africa. Postcolonial scholars see many strands of post- 
independence interventions in the Third World as a continuation of the parent/child ideology established in the nineteenth century.

The second dimension of the continuity of actually existing racism in the political economy of development is the widespread notion that the Third World is a late comer to modern life, meaning here a combination of capitalist economics, individualism, and ways of life. (Landes 2000, 11) The work of Max Weber and W.W. Rostow, though not racialized, did however formulate a temporal model which has allowed other thinkers to treat the Third World as kind of a left behind deformity, bogged down by backward cultures. At times, the racialization has been expressed in religious terms as in the aforementioned claim by Harrison that Latin America has been held back because of Catholicism. Some, such as David Landes go far as to say that 'success' in Catholic countries were actually achieved by the protestants, as he claims happened in France and Bavaria (Landes 2000, 12).

The so-called rise of the rest-the ongoing shift in material power away from the West and towards, above all, China-is making race more relevant to world politics, not less. For one thing, like Euro-America before it, China is now practicing its own form of colonialism in Africa, much of it under the guise of economic development. At a minimum, that is what the critics are suggesting.

\section{Race and Security}

In international relations, 'security' has traditionally focused on the military and economic security of mostly European great powers. This, too, has to do with a Eurocentric conception of the world. Consider the status of The Peloponnesian War by Thucydides in many textbooks. If 
Greco-Roman culture and civilization are assumed to be the foundations of Europe and the West, then in like manner the face-off between Athens and Sparta described therein may well be a natural point of departure for 'thinking the international.' Accordingly, many theorists who emphasize the competitive nature of great power politics - the so-called states under anarchy model-have long drawn on Thucydides to illustrate their dynamics of system structure, security dilemma, hegemonic transition and other theories and concepts used to explain international conflict. Thucydides's insights are today often deployed in debates about the ongoing tensions between the US and China (Buruma 2017) just like they were used a generation ago to illuminate the dynamics of the Cold War. Even Chinese President Xi Jinping felt compelled to join the fray, declaring, during his 2015 U.S. visit, that the so-called Thucydides trap-a potentially violent escalation caused by a newcomer's rise (Athens, China) and the fear this inspires in an established power (Sparta, United States)—is a myth.

A postcolonial sensibility stops us from falling in the trap of debating the Thucydides trap today (Barkawi 2010). In addition to warning against equating European history and Greco-Roman culture with global developments, postcolonial thinking makes us pause over the concept of anarchy, given its place in the history of anthropological thought and European colonialism (Sampson 2002). But if we must read The Peloponnesian War today, then why not subject it to a post-colonial reading? So viewed, the conflict between the Spartans and the Athenians was primarily a clash of opposing imperial systems - a 'democratic' maritime empire against an oligarchic land empire. This of course radically changes the content of 'lessons learned' that one draws from Thucydides as the focus of discussion becomes hierarchy, not anarchy-that is, how patron-client relations operate in war, how superordinate polities and their agents mobilize the 
subordinate, and how such large-scale violence sustains and transforms different political orders (Barkawi 2010).

As Barkawi $(2010,2017)$ and others have shown, the interconnection of 'security' with empire is overwhelming and multiply connected. For postcolonial scholars, many analytical goals in this area revolve around structural power, that is, around the question of how empires produce political, cultural, and social subjectivities. When nineteenth- and twentieth-century colonial agents conducted censuses of the local population and related research, they did so with imperial security in mind but what matters more are the new insecurities they created. Typically, the colonized peoples were enumerated and classified through a mix of interviews with local elites and the methods of scientific racism—skin color assessments and physiognomic measurements, some of which were done via photographs (Metcalfe 1995). In this process race was in fact grafted onto the intertwined and highly context-dependent local identities—caste, tribal, regional and religious - and the result was a system of knowledge that at once confirmed white supremacy and forced new divisions and discord on the colonized. Suffice it to say, such divideand-rule practices have left a lasting mark on most colonies and on the independent states that replaced them. As Mamdani (2002) argues, we cannot understand the 1994 Rwandan genocide without also understanding the colonial-era racialized identity formation.

A world in which international and inter-imperial relations were simultaneously or even primarily inter-racial relations was replete with race wars and race alliances, to use two fin-desiècle phrases. Race wars were waged especially in the colonies against the indigenous peoples. One example is the early twentieth century genocide of the Herero and Nama peoples in what was once called German South-West Africa and is today known as Namibia. (This war, note, is 
now revisited in multiple courts of justice with an eye towards setting a new standard in the idea and practice of international reparations).

For race alliances, take the Venezuelan crisis of 1895-a complex colonial territorial dispute that saw Britain and the US lock horns over their respective spheres of influence in the western hemisphere. From a liberal international relations perspective, the Anglo-American war was averted in this case thanks to the pacifying effect of democratic norms and democratic political structures-a so-called democratic peace. (Realists, in contrast, believe that the crisis was merely a 'near-miss'.) What the historical record shows, however, is sabre rattling quickly collapsing under the weight of transnational Anglo-Saxon supremacism. Why would the 'two trustees of civilization', asked one high-ranking U.S. policymaker at the time, 'fight over the mongrel state of Venezuela'? (Vucetic 2011: 34).

Fin-de-siècle beliefs in 'Anglo-Saxon unity' not only helped resolve other Anglo-American disputes in a peaceful fashion, but they also played a decisive role in the emerging structure of imperial alliances and rivalries, thus influencing the course of world history. In the SpanishAmerican (1898) and South African Wars (1899-1902), Anglo-Saxonism helped London and Washington act as each other's cheerleaders, which was crucial considering that all other imperial capitals favored, respectively, the Spaniards and the Boers (also see Klotz 2012).

Given that all racial identities are constructed, contingent, and changeable, the line between a race alliance and a race war was often thin. Take the Venezuela crisis of 1902-3 - a convenient shorthand for an even more complex colonial quarrel involving Venezuela, the US, Britain, Germany and Italy (Vucetic 2011: Ch.2). Like in 1895, the British and American elites declared themselves the 'two branches of the same race' and ended the tiff. Germany, heretofore touted as a potential member of a broader Anglo-Saxon-Teutonic race alliance, was cast as a racial Other, 
as 'the Goth and the shameless Hun', in the words of Rudyard Kipling who wrote a poem criticizing Britain's choice of allies in this policy situation (The Times, 22 December 1902). A full decade later, the same racialized alliance dynamics emerged anew, paving the road to the Great War. On December 8, 1912 Kaiser Wilhelm II convened an Imperial War Council at Potsdam to discuss the future of international order, an event many historians regard as a decisive step to the outbreak of conflict. There, Kaiser spoke of an existential war (Existenzkampf) between the Germans ('Austria, Germany') and the Slavs, the latter in alliance with the Latins (a.k.a. "Gauls") and eventually the Anglo-Saxons as well.

Western scholars sometimes forget that Clausewitz's much-abused dictum-war is a continuation of politics by other means-applied to the idea and practice of race wars well into the twentieth century. In World War II, the 'war without mercy' in the Pacific, like the treatment of 'lower races' as soldiers, prisoners of war, workers, and objects of strategy can all be regarded as continuations of the inter-racial politics that began in previous centuries (Dower 1986; Horne 2004). US race laws, and not just those associated with the Jim Crow regime in the South, impressed and inspired Nazi jurists in the 1930s. Indeed, the then US racist immigration control policies, anti-miscegenation laws and black disenfranchisement, segregation and lynching practices belong to the same colonialities of power as the Nazis' own Existenzkampf ideology.

Postcolonial perspectives shed new light on many large-scale 'tragedies' that accompanied World War II. Take the case of over three million Bengalis starving to death in 1943. The largest degree of responsibility for this famine-one of the worst of the twentieth century-goes to the British decision-makers. The colonial administers in India at the time could not be bothered to implement food price controls that would benefit their subjects, and neither could the war cabinet in London, when given a choice to divert food and aid from other theaters to India. British 
actions look even worse when we consider that no less than two and a half million soldiers drawn from British India fought in World War II. As Barkawi (2017) notes, this fact puts a completely different spin on the meaning of the 'British Army'. The same author reminds us that 'World War II' also incorporated many wars of decolonization. Take an extraordinary circumstance of soldiers from India, again in 1943, facing each other on the battlefield. On the one side, the British Indian Army fighting to save democracy denied by the same British they were fighting for; on the other side, the (Second) Indian National Army led by Subhas Chandra Bose fighting with Fascist Japan against the British colonizers (Barkawi 2017).

Like critical security studies scholars, postcolonial theorists are focused on non-state and nonmilitary referents of security, hence their occasional use of terms such as world security, cooperative security, comprehensive security and human security (Collins 2016). However, critical security studies scholars sometimes forget that these alternative notions of security have a long lineage in postcolonial theory. It is easy to see why: the history of modern Euro-American empires is defined by systemic violence designed and executed in the name of security-the security of trading routes, of strategic military bases, of settlers—and against various peoples racialized as non-white. Conversely, decolonization meant insecurity and radical changes to the order of things at home. As Barkawi wrote in 2010, 'Vietnam' remains the single most important event of the last half of the twentieth century for understanding US politics. The Algerian war led to regime change in France, as did wars of decolonization in Mozambique and Angola for Portugal.'

Along the same lines, we could again consider the Haitian Revolution and think about its (muchsilenced) impact on the events that changed the course of world history (Buck-Morss 2009). These include the votes in France's revolutionary legislatures to give "full rights for free blacks 
and mulattos" (1792) and to abolish slavery in the colonies (1794) as well as the debates that later led to the suspension of the international slave trade (Crawford 2002). Even the 1803 Louisiana Purchase, too- a bewildering stroke of a pen that doubled the size of the United States and enabled its "westward expansion"- - has everything to do with the then goings-on in Haiti.

The global expansion of Europe and later its offshoots was at once a configuration of economic, political, cultural, and military power. These aspects of power formed a comprehensive system both during the periods of conquest and colonization, as well as after European colonies (and other forms of foreign rule) were either pushed out or abandoned. In fact, the process of decolonization was quite often a bloody affair with enormous loss of life of Third World peoples. A cursory glance of the death toll of wars of liberation reveals the one- sided ness of the killing. Below is, for instance, is one entry from Michael Clodfelter's massive encyclopedia of war casualties between 1494 and 2007. The entry is for "Wars of Independence in Portuguese Africa: 1961-74"

Portuguese military and civilian dead - 4000 in Angola, 3,500 in Mozambique, 1,000 in Guinea; guerrilla dead-25,000 in Angola, 10,000 in Mozambique, 2,000 in Guinea; African civilian dead 50,000 in Angola, 30,000 in Mozambique, 5,000 in Guinea.

About 3,265 of the total Portuguese dead in the three wars were military personnel. (Clodfelter, 2008, 599; authors' emphasis).

Although the continuous killing in the Third World since conquest cannot be always directly linked to race and racism (Barkawi 2017), numerous writers, some postcolonial but certainly not all, have shown that Euro-American notions of racial supremacy have indeed influenced the forms and scales of killing. Marina Lazreg makes the point in compelling fashion when she 
argues that torture-a practice endorsed with various degrees of enthusiasm by successive United States presidents even in this century-'partakes in the work of the civilization in whose name it is practiced' (Lazreg 2007, 5). Further, unlike critical theories of hegemony which place emphasis on the construction of relations of exploitation though consensus, postcolonial and other critical scholars insist that the horror of violence is a definitive aspect of Western warfighting (Riley, Mohanty, \& Pratt 2008; Persaud 2016; Prashad 2016; Kumarakulasingam 2017; Mitamura 2017).

On the flip-side, the wars of the others have been thoroughly Orientalized or reduced to cultural or political backwardness. Patrick Porter $(2013,21)$ for instance, argues that '.. Westerners have voiced their fears about themselves, their survival, identity and values, through different visions of non-western warfare'. The reader would have noticed that Coldfelter characterization of who got killed in Angola, Mozambique, and Guinea. Postcolonialism sees these same wars as wars of liberation. The wars of liberation, were for nothing more than the key ingredient of the modern state system, namely sovereignty. Little wonder that so many theoretical binaries preferred by mainstream security studies—war/peace, internal/external, domestic/international, civil/military—are of limited purchase for postcolonial scholars.

\section{Key Points}

Race is not a biological fact but has been represented as such through pseudo-science such as eugenics. Race is a product of racism and racism is an ideology of power. Race is a signifier and because of that different things can, and for centuries have been, used to designate some populations superior to others. 
Race occurs both in practice and thought. Practice refers to action (anti-immigrant violence; war). The thought aspect can take many different forms, including philosophy, history writing, social and political theories, political rhetoric, and in the everyday thinking of small groups and individuals.

Ideologies and practices of racial supremacy have been consistently present in international relations, at least for the past five hundred years. The struggle for racial equality has been a persistent cause among those peoples and nations once colonized or conquered by for powers that claim to be superior.

Racial ideology and racism have affected almost all aspects of international relations including - the causes and conduct of wars, conceptions of national interest and foreign policy, global property relations, immigration and refugee policies, and also international cooperation. White supremacy and other forms of racism continue to shape perceptions of those nations and peoples who are other than white. Not talking about race, as in the ideology of colorblindness, tends to perpetuate white supremacy.

\section{Conclusion}

This chapter highlighted the multiple ways in which race and racism have influenced international relations both in terms of structures and actions, meaning both the underlying foundations and behavioral aspects of the international system. Our focus on the relationships among race on the one hand and theory, global governance, security, and economic development 
on the other, is not by any means exhaustive. This is so because race also affects a whole slew of other sectors of society including gender, class, nationalism, and among other things, the political economy of state finance (issue of welfare, education, healthcare),

Theorizing race is difficult because, as we have shown, there are disputes even about the most basic questions, such whether to continue engaging with the discourses of race or to eliminate it altogether from our discussion. Those who argue for eliminating hold that view because they think that talking about it is another way of guaranteeing its continuity. What is your view?

We have also shown that race and racism have been deeply embedded in the governance for several hundred years, and specifically so since 1492 with the advent of European conquest. The period of colonial rule saw direct and often violent structures and methods of governance over societies flung around the globe. Informal empire and imperial interference (such as the US foreign rule of the Philippines) continued where formal colonialism did not take hold. Even after decolonization (especially after WWII), Third World states have been subjected to coercive rule through multilateral mechanisms, such as humanitarian intervention, much of it based on assumptions of the inability of those states to properly govern themselves.

Race has had a devastating impact in terms of security relation broadly defined. Conquest which marked the beginning of the modern encounter between the European states and others, was exceptionally violent, with entire societies and people wiped out through the effects of slavery, European diseases, starvation, psychological trauma, and the direct application of physical violence, including numerous massacres and other forms of large scale violence. Many scholars are convinced that continuing violent intervention in the Third World, such as in the case of Iraq, are directly related to the racialized assumptions of Euro-American policy makers hold about Muslim societies. 
The impact of race on economic development has also been profound. As we have shown, world systems and dependency theorists, and also scholars working within the Marxist tradition have roundly concluded that the predominant feature of the relation between Euro-America and the Third World has been one of economic exploitation. Marxists have tended to stress the imperialist nature of capitalism as a system. World systems theory and dependency theory, both influenced by varieties of Marxian political economy provided comprehensive explanations of this economic exploitation through imperialism, but did not always place much emphasis on race. Some Third World historians such as Rodney did, however, factor-in racism in the explanation of underdevelopment.

A quick survey of international relations today would show that the problems of race and racism are still not only active, but also deeply divisive. The most poignant expressions of this are to be found in the general politics of immigration and refugee issues, where Euro-America is again concerned about, and resistant to, more people from the Third World coming in. While some of the concerns are economic, related as it were to competition for jobs, there are deeper feelings of racialized animosities. These lasts have found outward expression and structured mobilization in political parties and other 'civic' groups are imbued with discourses of a various forms of white supremacy. The rise of radical conservative politics has been so dramatic that the latest president of the United States will go down in history as someone who openly sided with neo-Nazis and the KKK. Race and racism manifest themselves in the mutable, context-dependent forms, which means that international relations scholars must continue to develop conceptual and political ways of understanding them, to say nothing of reflecting on their own position as both producers and products of the Eurocentric and ideological base of white supremacy. 


\section{Further Readings}

Du Bois, W.E.B. (1915), "The African Roots of War,"

http://scua.library.umass.edu/digital/dubois/WarRoots.pdf

A version of the Hobson-Lenin-Luxemburg theory of the imperialist origins of World

War I but with much-needed attention to racism. By one of the giants of social science.

Frantz, F. (1963). The Wretched of the Earth. New York: Grove Press.

Finished ten weeks prior to the author's death at the age of 36 , this is a pioneering book on race, colonialism, and decolonization.

Crenshaw, K. (1991), "Mapping the margins: Intersectionality, identity politics, and violence against women of color," Stanford Law Review, 1241-1299.

A groundbreaking conceptualization of racism by a leading thinker and scholar in the field of critical race theory today.

James, J. (1998). The Angela Y. Davis Reader. Oxford: Blackwell.

A collection of writings by a revolutionary, radical public intellectual and a living witness of the anti-racist struggles in the contemporary era.

Jones, B.G. (Ed.). (2006). Decolonial International Relations. Lanham: Roman \& Littlefield. An excellent collection of decolonial essays by scholars from both the global north and global south.

Painter, N. (2010). A history of White People. Princeton: Princeton University Press. A highly acclaimed book that traces the historical and intellectual development of race and racism across regions and cultures, with a focus on the emergence of 'white people' as a cultural category.

Sajed, A. (2013) Postcolonial Encounters in International Relations: The politics of transgression in the Maghreb. New York: Routledge.

A close up reading of French colonial practices in North Africa, and an insightful analysis of how the memories of colonialism linger. 


\section{Notes}

\footnotetext{
${ }^{1}$ We are grateful to Catherine Baker, Alexander Davies, Audie Klotz, and Ajay Parasram for their valuable input during the writing of this chapter. All standard disclaimers apply.

${ }^{2}$ Mainstream international relations textbooks, collections and bibliographic compendia have only recently started soliciting chapters on race. See, respectively: Shilliam (2017); Klotz (2017); and Búzás (2017); and compare with
} Doty (1996), Sampson (2002), Hobson (2012), Henderson (2014), Krishna (2001) and Persaud and Walker (2001).

${ }^{3}$ The concept draws on the work of Frantz Fanon, among others (Shilliam 2017: 292; Further readings).

${ }^{4}$ Similar cost-benefit analyses inform Orientalist knowledge we discussed in the previous section. Why critically interrogate colonialism when it benefits the West to pretend that the material circumstances of the Third World are fundamental expressions of an inner culture not consistent with modernity?

${ }^{5}$ These forms of racism are idea types—as abstractions distilled from concrete phenomena that serve to categorize, compare and contrast complex social systems. To better understand how cultural racism relates to other forms of racism and nearby forms of oppression, see, for example, Martínez's (2008) analysis of the relationship between colonial Mexico's sistema de castas and the late fifteenth century Spanish concept of "purity of blood" or limpieza de sangre.

${ }^{6}$ This is why chattel slavery must be seen as qualitatively different from the previous enslavements of people from sub-Saharan Africa and other modern forms of oppressions involving "black" people (the practice "blackbirding" in the colonial-era Pacific, for example). For an informative foray into the history of blackness from the perspective of the 18th century Atlantic, see Nussbaum (2009) for example.

${ }^{7}$ Much like the present-day talk of reparations for slavery, the present-day talk of France repaying some of these extorted moneys to Haiti remains just that—talk.

${ }^{8}$ Key developments in the middle years of the twentieth century include the 1950 UNESCO statement on race, the 1955 Bandung conference, Black Power and the US civil rights movement in the 1960s, and the 1963 Security Council decision to sanction apartheid South Africa (Shilliam 2017, 290, 292-3; Klotz 2017: 372-377). 


\section{Bibliography}

Barkawi, T. (2010). Empire and order in international relations and security studies. In R.A.

Denemark \& R. Marlin-Bennett (Eds.). The International Studies Encyclopedia (pp. Online

2017. (Guidance Need for this entry)

Barkawi, T. (2017). Soldiers, of empire: Indian and British armies in world war II. Cambridge:

Cambridge University Press.

Bhambra, Gurminder (2007). Rethinking Modernity: Postcolonialism and the Sociological Imagination. Palgrave MacMillan: Basingstoke.

Buck-Morss, S. (2009). Hegel, Haiti and universal history. Pittsburgh, PA: University of Pittsburgh Press.

Búzás, Z. (2017). Race and international relations.” Oxford Bibliographies. doi: 10.1093/OBO/9780199743292-0197.

Benton, Lauren A. (2010). A search for sovereignty: Law and geography in European empires, 1400-1900. Cambridge, UK: Cambridge University Press.

Buruma, I. (2017). Are China and the United States headed for war? The New Yorker. Last modified June 19, 2017. http://www.newyorker.com/magazine/2017/06/19/are-chinaand-the-united-states-headed-for-war.

Chakrabarthy, D. (2000). Provincializing Europe. Princeton: Princeton University Press.

Chowdhry, G. and Nair, S. (2003). Power, postcolonialism and international relations: Reading, race, gender, and class. New York: Routledge. 
Chowdhry, G. and Rai, S.M. (2009) The geographies of exclusion and the politics of inclusion: race-based exclusion in the teaching of international relations. International Studies Perspectives. 10, 84-91.

Collins, A. (2016). Contemporary security studies. New York: Oxford University Press.

Clodfelter, M. (2008). Warfare and armed conflicts: A statistical reference to casualty and other figures, $1494-2007$ ( $3^{\text {rd }}$ Edition). Jefferson, North Carolina.

Cox, R.W. (1987) Production, power, and world order: social forces in the making of history. New York: Columbia University Press.

Crawford, N. (1994). A security regime among democracies: Cooperation among Iroquois Nations," International Organization, 48, 345-385.

Crawford, N.C. (2002) Argument and change in world politics: Ethics, decolonization, and humanitarian intervention. Cambridge: Cambridge University Press.

DeGuzmán, M. (2005). Spain’s long shadow: The black legend, off-whiteness, and AngloAmerican empire. Minneapolis: University of Minnesota Press.

Denemark, R.A. and Marlin-Bennett, R. (ed.) The International studies encyclopedia, (pp. 13601379). Chichester: Wiley Blackwell.

Doty, R.L. (1996). Imperial encounters: The politics of representation in north-south relations. Minneapolis, MN: University of Minnesota Press.

Dower, J. (1986). War without mercy: Race and power in the Pacific War. New York: Pantheon.

Fredrickson, G.M. (2002) Racism: A Short History. Princeton: Princeton University Press. 
Gong, G.W. (1984). The standard of 'civilisation' in international society. Oxford: Clarendon Press.

Grovogui, S.N. (1996). Sovereigns, quasi sovereigns, and Africans: Race and self-determination in international law. Minneapolis: University of Minnesota Press.

Guha, R. (1982). Subaltern studies I: Writing on South Asian history and society. New Delhi: Oxford University Press.

Inayatullah, N, and Blaney, D. L. (2004). International relations and the problem of difference. London: Routledge.

Harrison, L.E. (1998). The Pan-american dream: Do Latin America's cultural values discourage true partnership with the United States and Canada? Boulder: Westview Press.

Harrison, L. and Huntington, S.P. (2001) Culture Matters. New York: Basic Books.

Henderson, E.A. (2015). Hidden in plain sight: Racism in international relations theory. In A. Anievas, N. Manchanda \& R. Shilliam (Eds.). Race and racism in international relations: Confronting the global colour line (pp.19-43) New York: Routledge.

Hobson, J.M. (2012). The Eurocentric conception of world politics: Western international theory, 1760-2010. Cambridge: Cambridge University Press.

Horne, G. (2004). Race war: White supremacy and the Japanese attack on the British Empire. New York: New York University Press.

Kendi, I.X. (2016) Stamped from the beginning: The definitive history of racist ideas in America. New York: nation Books. 
Klotz, A. (2017). Racial inequality. In T. Dunne \& C. Reus-Smith (Eds.). The globalization of international society (pp. 362-379). Oxford: Oxford University Press.

Klotz, A. (2012). The imperial self: A perspective on Anglo-America from South Africa, India, and Ireland," In P. Katzenstein (Ed.). Anglo-America and its discontents: Civilizational identities beyond East and West (pp. 81-104). New York: Routledge.

Krishna, S. (2001). Race, Amnesia, and the Education of International Relations. Alternatives 26, 401-24.

Kumarakulasingam, N. (2017). Metropolitan killings: Laundering a scandal. Paper presented at the $58^{\text {th }}$ International Studies Association Convention, Baltimore, MD.

Landes, D (1990). "Why are we so rich and they so poor? The American Economic Review, 80, $1-13$.

Lauren, P.G. (1996). Power and prejudice: The politics and diplomacy of racial discrimination. Boulder, Colorado: Westview Press.

Lazreg, M. (2016). Torture and the twilight of empire: From Algiers to Baghdad. Princeton: Princeton University Press

Lentin, A. (2015). Racism in public or public racism: doing anti-racism in "post-racial" times. Ethnic and Racial Studies 39, 33-48.

Lentin, A. (2017). "De-Racing the Border," a blog post, 11 May 2017. http://www.alanalentin.net/2017/05/11/de-racing-the-border/

Lightfoot, S. (2016). Global indigenous politics: A subtle revolution. London: Routledge. 
Malik, K (2009) Strange fruit: Why both sides are wrong in the race debate. Oxford: One World.

Mamdani, M. (2002). When victims become killers: Colonialism, nativism, and the genocide in Rwanda. Princeton, NJ: Princeton University Press.

Martínez, M.E. (2008). Genealogical fictions: Limpieza de sangre, religion, and gender in colonial Mexico. Stanford, CA: Stanford University Press.

Matlon, J. (2016) Racial capitalism and the crisis of black masculinity. American Sociological Review, 81, 1014-1038.

McCarthy, T. (2007). Race, empire, and the idea of human development. Cambridge: Cambridge University Press.

Metcalfe, T. (1995). Ideologies of the Raj. Cambridge: Cambridge University Press.

Mills, C.W. (2015) Global white ignorance. In Routledge international handbook of ignorance studies. (pp. 217-227). New York: Taylor and Francis Inc.

Mitamura, E. (2017). Provoking humanity: Afterlives of mass violence in Cambodia and the United States. Paper presented at the $58^{\text {th }}$ International Studies Association, Baltimore, MD.

Mittelman, J.H. (2009). The Salience of Race. International Studies Perspective, 99-107.

Murphy, E. (2009). Women's anti-imperialism, 'The white man's burden,' and the PhilippineAmerican war," Gender \& Society, 23, 244-270.

Nussbaum, F.A. (2009). Between 'oriental' and 'blacks so called,' 1688-1788.” Postcolonial enlightenment: Eighteenth-century colonialism and postcolonial theory. In D. Carey, \& Lynn Festa (Eds.). (pp.137-66). Cambridge: Cambridge UP. 
Painter, N.I. (2010) The History of White People. New York: W.W. Norton \& Co.

Persaud, R.B. (2001). Counter-hegemony and foreign policy: The dialectics of marginalized and global forces in Jamaica. Albany: SUNY Press.

Persaud, R.B. \& Walker R.B.J. (2001b). Apertura: Race in international relations.” Alternatives 26, 373-76.

Persaud, R.B. (2016) Neo-Gramscian theory and third world violence: a time for broadening. Globalizations, Vol, 13, 547-564.

Porter, P. (2013). Military orientalism: Eastern war through western eyes. New York: Oxford University Press.

Prashad, V. (2016). The death of a nation and the future of the Arab revolution. Berkeley, CA: University of California Press.

Riley, R., \& Inayatullah, N. (2006). Interrogating imperialism: Conversations on gender, race, and war. New York, NY: Palgrave Macmillan.

Riley, R., Mohanty, C. and Pratt, M.B. (2008). Feminism and war: Confronting U.S. imperialism. London: Zed Books.

Rodney, W. (1981). How Europe underdeveloped Africa. Washington D.C.: Howard University Press. Suzuki, Shogo (2009). Civilization and Empire: China and Japan's Encounter with European International Society, London \& New York: Routledge.

Quijano, A. (2000). 'Coloniality of power and Eurocentrism in Latin America'. International Sociology, 15, 215-232. 
Quỳnh, N.P. and Shilliam, R. (Eds.) (2016). Meanings of Bandung: Postcolonial Orders and Decolonial Visions. Lanham, MD.: Roman \& Littlefield Publishers.

Said, E. (1979). Orientalism. New York: Vintage.

Sajed, A. (2013). Postcolonial encounters in international relations: The politics of transgression in the Maghreb. New York: Routledge.

Sampson, A.B. (2002). Tropical anarchy: Waltz, Wendt, and the way we imagine international politics. Alternatives, 27, 429-457.

Seth, S. (Ed.) (2013). Postcolonial theory and international relations. London: Routledge.

Sabaratnam, M. (2017). Decolonizing intervention: International statebuilding in Mozambique.

London: Routledge.

Shilliam, R. (2017). Race in world politics. In S. Smith, P. Owens, J. Baylis (Eds.) The

Globalization of World Politics (pp.286-300). Oxford UP.

Shimazu, N. (1998). Japan, race and equality: The racial equality proposal of 1919. New York: Routledge.

Spivak, G. C. (1988). Can the Subaltern Speak? In C. Nelson \& L. Grossberg, Marxism and the interpretations of culture (pp. 271-313). Basingstoke: Macmillan Education.

Stewart-Harawira, M. (2005). The new imperial order: Indigenous responses to globalization. London: Zed Books.

Streets, H. (2004). Martial races: The military, race and masculinity in British imperial culture, 1857-1914. Manchester, UK: Manchester University Press. 
Suzuki, S. (2009). Civilization and empire: China and Japan's encounter with European international society. London \& New York: Routledge.

Todorov, T. (1999). The Conquest of America: The Question of the Other. Tulsa: University of Oklahoma Press.

Toussaint, C.E. (1956). The trusteeship system of the United Nations. New York: Praeger.

Trouillot, M. (1995). Silencing the past: Power and the production of history. Boston, MA: Beacon Press.

Pijl, K.v.d. (2014) The discipline of western supremacy: Modes of foreign relations and political economy. Vol. III. London: Pluto Press.

Vitalis, R. (2016). White world order, Black power politics: The birth of international relations. Ithaca: Cornell University Press.

Vucetic, S. (2011). The Anglosphere: A genealogy of racialized identity in international relations. Stanford: Stanford University Press.

Vucetic, S. (2012). The search for liberal Anglo-America: From racial supremacy to multicultural politics. In P. Katzenstein (Ed.). Anglo-America: Civilizational politics beyond West and East, 120-141. London: Routledge.

Vucetic, S. (2015). Against race taboos: The global colour line in philosophical discourse. In A. Anievas, N. Manchanda \& R. Shilliam (Eds.). In Race and racism in international relations: confronting the global colour line (98-114). Abingdon: Routledge. 
Walker, R.B.J. (2006). Lines of Insecurity: International, Imperial, Exceptional. Security

Dialogue. 37, 65-82.

Watson, H. (2001). Theorizing the racialization of global politics and the Caribbean experience. Alternative. 26, 449-483.

Williams, G., Meth, P. \& Willis, K. (2014). Geographies of developing areas: the global south in a changing world ( $2^{\text {nd }}$ edition). New York: Routledge.

Young, R.J.C. (1995). Colonial desire: Hybridity in theory, culture and race. London:

Routledge. 